Rev. Int. Contam. Ambie. 34 (3) 505-516, 2018

DOI: $10.20937 /$ RICA.2018.34.03.12

\title{
TOXIC EFFECTS OF EXPOSURE TO PESTICIDES IN FARM WORKERS IN NAVOLATO, SINALOA (MEXICO)
}

\author{
José Guillermo GALINDO-REYES ${ }^{1}$ and Henry ALEGRIA ${ }^{2 *}$
}

${ }^{1}$ Facultad de Ciencias del Mar, Universidad Autónoma de Sinaloa, Paseo Claussen s.n., Col. Los Pinos, 80000 Mazatlán, Sinaloa, México

${ }^{2}$ College of Arts and Sciences, University of South Florida St. Petersburg, 140 7th Avenue S, St. Petersburg, FL 33701, USA

*Author for correspondence: halegria@mail.usf.edu

(Received March 2017; accepted October 2017)

Key words: soil, water, blood, urine, clinical analyses

\begin{abstract}
The impact of chronic exposure to pesticides, especially among farmworkers, continues to be an area of research interest, especially in developing countries. This study aimed to measure and compare levels and profiles of pesticides in farm environments and farmworkers in an agricultural area of Mexico, as well as their effects in this cohort. Organochlorine and organophosphate pesticides were measured in soil and water samples from farms in the Navolato Valley, Sinaloa, Mexico. Levels of these pesticides as well as transaminases, alkaline phosphatase, acetylcholinesterase and hemoglobin were also measured in blood and urine from farmworkers of the study area and compared with levels in a control population. All 17 target organochlorine pesticides and four of nine target organophosphate pesticides were detected in soil and water samples. In farmworkers, 14 of 17 target organochlorine pesticides and seven of nine organophosphate pesticides were detected. Pesticide profiles were similar in farmworkers as in the environment. In comparison, only six organochlorine pesticides and three organophosphate pesticides were detected in control population, in much lower concentrations and with lower detection frequencies. Clinical analyses indicated that levels of transaminases and alkaline phosphatase were elevated while levels of hemoglobin and acetylcholinesterase were depressed in farmworkers compared to the control group. The results indicate that farmworkers are suffering from chronic exposure to workplace pesticides and could endure adverse health effects.
\end{abstract}

Palabras clave: suelo, agua, análisis clínicos, sangre, orina

\section{RESUMEN}

El impacto de la exposición crónica a plaguicidas —especialmente entre los trabajadores agrícolas- es un área de interés para la investigación, especialmente en los países en desarrollo. Este estudio tuvo como objetivo medir y comparar los niveles y perfiles de los plaguicidas en el medio ambiente y los trabajadores agrícolas en una zona agrícola de México, así como sus efectos en este grupo de personas. Los niveles de plaguicidas 
organoclorados y organofosforados se midieron en muestras de suelo y agua de campos agrícolas del valle de Navolato, Sinaloa, México. También se midieron los niveles de estos pesticidas en sangre y orina de los trabajadores agrícolas del área de estudio, así como las enzimas transaminasas, fosfatasa alcalina, acetilcolinesterasa y la hemoglobina, y se compararon con los niveles en una población de control. En las muestras de suelo y agua se detectaron los 17 plaguicidas organoclorados objetivo y cuatro de los nueve plaguicidas organofosforados. En los trabajadores agrícolas se detectaron 14 de los 17 plaguicidas organoclorados objetivo y siete de los nueve organofosforados. Los perfiles de plaguicidas fueron similares tanto en el medio ambiente como en los trabajadores agrícolas. En comparación, en la población de control sólo se detectaron seis plaguicidas organoclorados y tres organofosforados en concentraciones mucho menores y con más baja frecuencia de detección. Los análisis clínicos indicaron que los niveles de transaminasas y fosfatasa alcalina estuvieron elevados, mientras que los de hemoglobina y acetilcolinesterasa disminuidos en los trabajadores agrícolas en comparación con el grupo control. Estos resultados indican que los trabajadores agrícolas pueden presentar efectos de salud adversos por exposición crónica a plaguicidas en su lugar de trabajo.

\section{INTRODUCTION}

Pesticides are known environmental pollutants which have a long history of use in agriculture and in the control of vector-borne diseases. Many pesticides bioaccumulate in plants and animals, including humans, and biomagnify through food chains (BroRasmussen 1996, De-Qing et al. 2012, Nilsen et al. 2014, Luo et al. 2016, Thomas et al. 2017). Some pesticides are known or suspected carcinogens in humans and other organisms. Pesticides have been implicated in chronic and acute diseases such as leukemia, cancer, thyroid and nervous disorders, endocrine disruption and others (Lee et al. 2004, Freeman et al. 2005, Recio et al. 2005, Lacasaña et al. 2010, Alavanja and Bonner 2012, Starks et al 2012, Blanc-Lapierre et al. 2013, Michalakis et al. 2014, Dhouib et al. 2016, Piccoli et al. 2016, IARC 2017, Polanco Rodríguez et al. 2017). Due to their environmental risk and toxicity, the use of certain pesticides has been restricted or banned in many countries. Nevertheless, in many developing countries there is often insufficient control over both the sale and the appropriate use (as per manufacturer specifications and environmental regulations) of many pesticides.

The impacts of inappropriate use of pesticides on the environment and on public health in developing countries and countries in transition are well known. The International Register on Potentially Toxic Chemical Products (Rickert 1993) and the Free Prior and Informed Consent program of the Food and Agricultural Organization (FAO, 1993) are important first steps to report the abuses and inappropriate uses of agricultural chemicals that continue to be a serious problem in many countries in Latin America, Asia and Eastern Europe (Andreoli 1993).

The state of Sinaloa, in northwestern Mexico, is the country's leading agricultural state, sometimes being known as the "breadbasket of Mexico". Sinaloa is the main producer of export-oriented products in Mexico (SAGARPA 2011). It produces nearly 10 million tons of agricultural products and uses 7000$8000 \mathrm{t}$ of pesticides. In Sinaloa, the municipality of Navolato is ranked fourth in terms of intensive agriculture, with over 84000 ha under irrigation year-round (INEGI 2016). Within the Navolato valley, the main agricultural products are vegetables, sugarcane, rice, beans, sorghum, wheat, soy, corn and cotton, which are sold as industrial supplies and exported nationally and internationally, mainly to the United States. Navolato is also the municipality with the largest number of migrant farmworkers (over $20 \%$ of the population) who are mainly from the states of Oaxaca, Guerrero, Zacatecas and Durango. This is due mainly to the large demand of seasonal farmworkers for the cultivation and harvesting of vegetables and grains.

Previous studies have documented the presence of pesticides in coastal ecosystems of Sinaloa, which are the final receptors of agrochemicals used in agricultural valleys. Galindo et al. (1992) reported the presence of methoxychlor, $\gamma$-hexachlorocyclohexane (lindane), dichloro-diphenyl-trichloroethane (DDT), endosulfan, dieldrin, chlordanes and other pesticides in water, sediments and shrimp from the Teacapan estuary located in southern Sinaloa. Another report (Galindo et al. 1997) 
documented levels of lindane, aldrin, DDT, heptachlor, dieldrin and methyl parathion in water and sediments of the Huizache Caimanero lagoon, one of the most productive coastal water bodies in southern Sinaloa.

More recently, attention has been drawn in Mexico to the public health effects of pesticide contamination. Reports from the news media have suggested that intensive pesticide usage in agriculture has resulted not only in acute intoxication cases but also in chronic diseases among farm workers and populations near farmlands (Ramírez and Galindo 2014). Therefore, the aim of this study was to measure levels of pesticides in soil, water and farmworkers in the Navolato valley of Sinaloa to determine the potential impact of these chemicals in its population.

\section{METHODS AND MATERIALS}

\section{Sampling}

Bimonthly soil and water samples were collected from eight farms in the Navolato valley, Sinaloa (Fig. 1) during six sampling campaigns between June 2013 and July 2014. Blood and urine samples were also collected from volunteer farm workers from these farms in July 2013.

Soil samples were collected from areas between rows of crops by digging up the top $10 \mathrm{~cm}$ of soil with a clean stainless-steel garden spade (500-600 g). The spade was rinsed with distilled water between each sample. One soil sample was collected at each farm from an area randomly selected. Soil collected was stored in pre-cleaned Al foil and placed in a Ziploc bag for transportation to the laboratory.

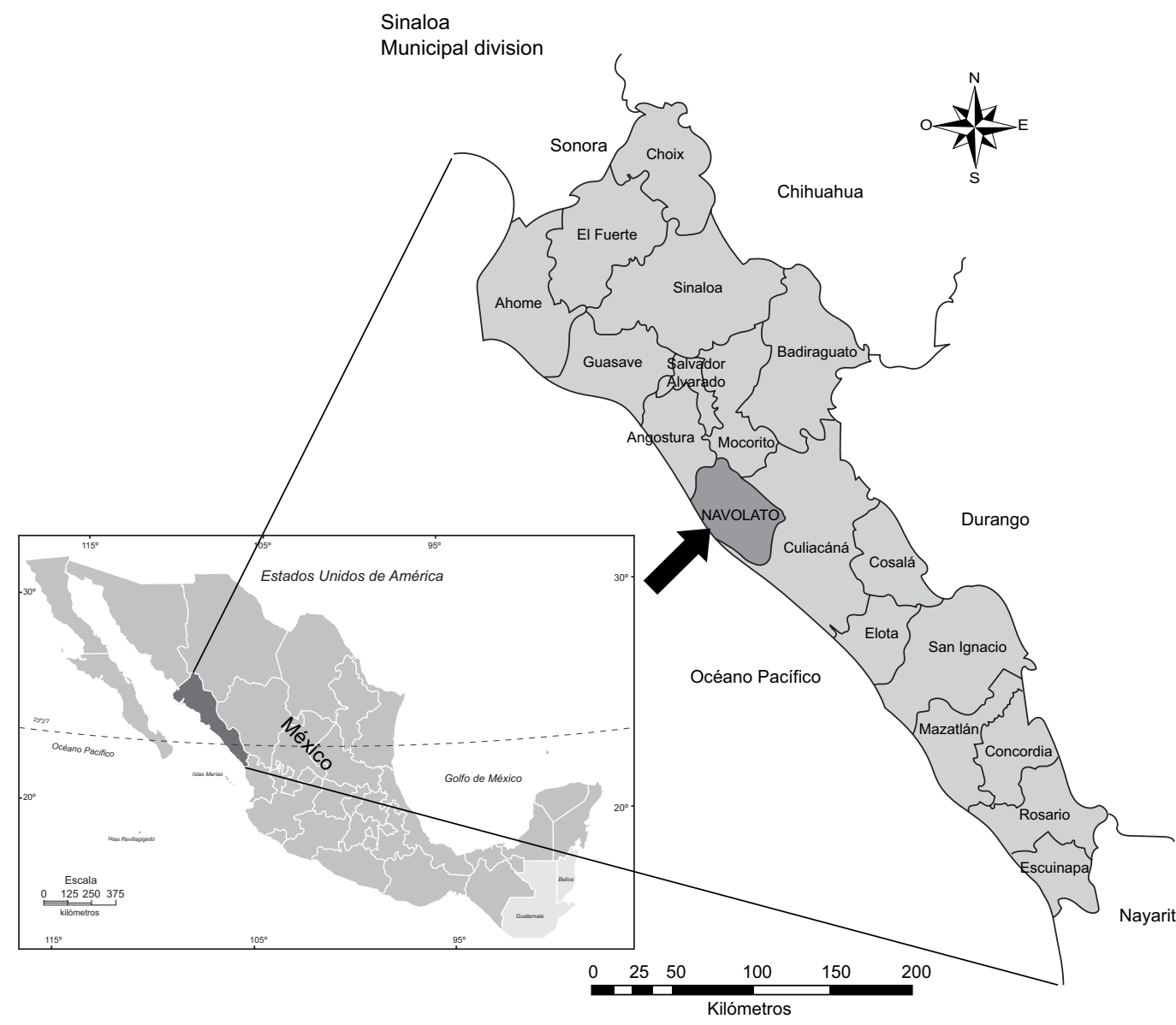

Fig. 1. Navolato is a municipality of the state of Sinaloa. It is located in northwestern Mexico at $24^{\circ} 45^{\prime} 49.62^{\prime \prime} \mathrm{N}$, $107^{\circ} 42^{\prime} 5.21^{\prime \prime}$ W, close to the Tropic of Cancer $\left(23^{\circ} 26^{\prime} 13^{\prime} \mathrm{N}\right)$, with a surface of $2285 \mathrm{~km}^{2}$ 
Water samples were collected from drains at each farm. Samples were collected by dipping pre-cleaned 4-L glass bottles by hand at a depth of about $15 \mathrm{~cm}$. Bottles were stored in coolers with ice until extraction the same day in the laboratory.

Urine $(100-150 \mathrm{~mL})$ and blood $(20 \mathrm{~mL})$ samples were collected from 49 farmworkers from the study sites who volunteered for the study (ranging from 18 to 42 years of age, $30 \%$ females and $70 \%$ males, all fieldworkers) and a control group consisting of 20 inhabitants from the city of Mazatlan, Sinaloa who have never been employed in farming (ranging in age from 19 to 40 years of age, $40 \%$ females and $60 \%$ males, employed in various non-agricultural activities). Blood was collected by puncture from the arms of volunteers using BD Vacutainer ${ }^{\circledR}$ tubes. Urine was collected in sterile containers following standard protocols.

\section{Extraction and cleanup}

Water samples were extracted by liquid-liquid extraction using methylene chloride. Each 4-L sample was divided into $500 \mathrm{~mL}$ aliquots in a 1-L separatory funnel and each aliquot was extracted twice with 100-mL dichloromethane (DCM). All extracts were combined and concentrated to approximately $1 \mathrm{~mL}$ via rotary evaporation followed by a gentle stream of ultrapure nitrogen and solvent-exchanged into hexane.

Soil samples were sieved to get rid of rocks and roots and then combined and thoroughly mixed and homogenized. For each sample, a 100-200 g subsample was mixed thoroughly with anhydrous sodium sulfate, and from each subsample $40 \mathrm{~g}$ were placed in a glass thimble and Soxhlet-extracted overnight with $250 \mathrm{~mL}$ 1:1 DCM:hexane. Extracts were concentrated to $1 \mathrm{~mL}$ via rotary evaporation followed by a gentle stream of ultrapure nitrogen and solvent-exchanged into hexane ultrapure nitrogen and solvent-exchanged into hexane.

Water and soil extracts were both cleaned up by column chromatography using a column consisting of $4 \mathrm{~g}$ Florisil $+4 \mathrm{~g}$ silica gel $+4 \mathrm{~g}$ alumina and finally overlain with $2 \mathrm{~g}$ anhydrous sodium sulfate. After pre-elution with dichloromethane and hexane, samples were loaded on the column and eluted first with $100 \mathrm{~mL}$ hexane (F1) followed by $100 \mathrm{~mL} \mathrm{DCM}$ (F2). F1 contained organochlorine (OC) pesticides and F2 contained organophosphate (OP) pesticides. Both fractions were concentrated to $\sim 100-200 \mu \mathrm{L}$ with a rotary evaporator followed by a gentle stream of nitrogen gas, then solvent exchanged with isooctane and again concentrated to $1 \mathrm{~mL}$ with a gentle stream of nitrogen gas (CNR 1983).
Urine samples were acidified with a solution of tartaric acid (pH 5-6) and a 10-mL subsample was shaken mechanically (Vortex) twice with $5 \mathrm{~mL}$ DCM in a glass tube for $1 \mathrm{~min}$. Each time, the organic layer was separated; they were combined and dried by passage through a glass pipette packed with a $3-\mathrm{cm}$ layer of anhydrous sodium sulfate. The extract was evaporated to dryness under a gentle nitrogen stream at $40^{\circ} \mathrm{C}$ and the residue was dissolved in $1 \mathrm{~mL}$ hexane and analyzed for OP pesticides.

One half $(10-\mathrm{mL})$ subsample of blood was used for pesticide analysis. The serum component was separated, diluted with deionized water $(5 \mathrm{~mL})$ and extracted with petroleum ether $(5 \mathrm{~mL})$. The mixture was ultra-centrifuged and the organic phase removed, dried with anhydrous sodium sulfate, concentrated under a gentle nitrogen stream and solvent-exchanged into hexane to a final volume of $1 \mathrm{~mL}$.

Blood extracts were cleaned by subjecting to a micro-column packed with Florisil. Extracts were eluted with $10 \mathrm{~mL}$ petroleum ether. The eluate was concentrated and solvent-exchanged into hexane and analyzed for OC pesticides.

The second half of the blood sample was sent to the clinical laboratory of the Martiniano Carvajal Hospital in Mazatlan, where the following analyses were carried out: differential hematic biometry, blood chemistry, and enzymes alkaline phosphatase, transaminases, and acetylcholinesterase.

\section{Analysis}

OC pesticides targeted in this study were: the isomers ( $a, b, g, d)$ of hexachlorocyclohexane (HCHs), p,p'-DDT, p,p'-DDE, p,p'-DDD, endrin, aldrin, dieldrin, endrin aldehyde, heptachlor, heptachlor epoxide, methoxychlor, endosulfan I and II, and endosulfan sulfate. Organophosphate pesticides targeted were: famfur, parathion, methyl parathion, disulfuton, diazinon, dimethoate, phorate, sulfotep, thionazin and triethylphosphorothioate. These pesticides represent legacy pesticides that were used in the region in the past (OC pesticides except endosulfans) and those registered for use in Mexico (endosulfans and organophosphate pesticides), which may be consulted in the pesticides catalogue of the Federal Commission for the Protection against Sanitary Risks (COFEPRIS, 2015).

OC pesticides were identified and quantified using a Shimadzu GC-17A chromatograph equipped with a ${ }^{63} \mathrm{Ni}$ detector and a DB-5 column $(30 \mathrm{~m} \times 0.25 \mathrm{~mm}$ i.d. $\times 0.25 \mathrm{~m}$ film thickness, J\&W Scientific). The injector was kept at $275^{\circ} \mathrm{C}$ and the detector at $290{ }^{\circ} \mathrm{C}$. 
One $\mu \mathrm{L}$ was injected in splitless mode. The following oven temperature program was used: initial temperature $90{ }^{\circ} \mathrm{C}$ held for $1 \mathrm{~min} ; 5{ }^{\circ} \mathrm{C} / \mathrm{min}$ to $150{ }^{\circ} \mathrm{C}$, held for $1 \mathrm{~min} ; 1.5^{\circ} \mathrm{C} / \mathrm{min}$ to $240^{\circ} \mathrm{C}$; then $10^{\circ} \mathrm{C} / \mathrm{min}$ to $290{ }^{\circ} \mathrm{C}$, held for $10 \mathrm{~min}$. Helium was used as a carrier gas at $1.5 \mathrm{ml} / \mathrm{min}$.

The OP pesticides were identified and quantified using a Shimadzu GC-17A equipped with a flame ionization detector (FID) and a DB-5 column $(30 \mathrm{~m} \times 0.25 \mathrm{~mm}$ i.d. $\times 0.25 \mathrm{~m}$ film thickness, J\&W Scientific). The injector and detector were kept at $250{ }^{\circ} \mathrm{C}$. One $\mu \mathrm{L}$ was injected in split/splitless mode (purge time of $0.75 \mathrm{~min}$ and split of 1:50). The following oven temperature was used: initial temperature of $60{ }^{\circ} \mathrm{C}$, held for $1 \mathrm{~min}$, increased at $30{ }^{\circ} \mathrm{C} / \mathrm{min}$ to $150^{\circ} \mathrm{C}$, held for $4 \mathrm{~min}$, then increased at $5{ }^{\circ} \mathrm{C} / \mathrm{min}$ to $240{ }^{\circ} \mathrm{C}$, held for $5 \mathrm{~min}$. Helium was used as a carrier gas. The FID was fed by synthetic air at $300 \mathrm{~mL} / \mathrm{min}$ and hydrogen gas at $30 \mathrm{~mL} / \mathrm{min}$.

Pesticides were identified by comparing retention times to those of pure standards run under the same conditions (relative retention time match within 0.005 min of the relative retention time for pure standards). They were quantified versus the internal standard and a five-point calibration curve for each target pesticide established under the same conditions as those used to run the samples.

\section{Quality control}

The recovery of pesticides was determined by spiking $500 \mathrm{~mL}$ of e-pure water $(\mathrm{n}=5)$ and $10 \mathrm{~g}$ of clean soil ( $\mathrm{n}=5$, Soxhlet-extracted three times with 1:1 DCM:hexane) with a solution of target pesticides of known concentration treated as samples. Percent recoveries ranged from 75 to $92 \%$. Two $\mathrm{L}$ of deionized water $(\mathrm{n}=5)$ were extracted and the extracts treated identically to water samples to serve as blanks. Soxhlet thimbles containing 15 $\mathrm{g}$ of anhydrous sodium sulfate were extracted as blanks for soils $(n=5)$ and the extracts underwent the same procedures as soil samples. Solvent blanks $(\mathrm{n}=10)$ were run during analysis of samples. In all blanks, target pesticides were not detected. Instrumental detection limits (IDLs) were estimated by injecting low concentrations of target analytes until a small peak at 3:1 signal-noise ratio was obtained. For soils, IDLs are expressed in $\mu \mathrm{g} / \mathrm{g}$ and for water samples IDLs are expressed as $\mu \mathrm{g} / \mathrm{L}$. For organochlorine pesticides, IDLs ranged from 0.03$0.05 \mu \mathrm{g} / \mathrm{g}$ for soil and $0.02-0.05 \mu \mathrm{g} / \mathrm{L}$ for water. For organophosphate pesticides, IDLs ranged from 0.05 $-0.06 \mu \mathrm{g} / \mathrm{g}$ for soils and from $0.001-0.005 \mu \mathrm{g} / \mathrm{L}$ for water.

\section{RESULTS}

\section{Pesticide concentrations in water and soil}

Table I summarizes the concentrations of pesticides in water and soil. Since the objective of this study was to determine if any pesticides measured in the environment are also detected in blood and urine of farmworkers we simply present annual averages of each type of pesticide measured and the overall frequency of detection of 48 samples (eight farms $\times$ six sampling periods).

All target OC pesticides were detected in soil and water samples in at least some samples. Frequency of detection ranged from $38 \%$ (aldrin) to $100 \%$ (g-HCH, heptachlor, p,p'-DDE and methoxychlor) in soil and from $8 \%$ (b-HCH) to $100 \%$ (endosulfan sulfate, p,p'-DDD and methoxychlor) in water. Annual average levels ranged from $0.460 \mu \mathrm{g} / \mathrm{g}$ (endrin) to $7.574 \mu \mathrm{g} / \mathrm{g}$ (methoxychlor) in soils and from 0.011 $\mu \mathrm{g} / \mathrm{L}$ (b-HCH) to $0.565 \mu \mathrm{g} / \mathrm{L}$ (methoxychlor) in water. The standard deviations did not indicate significant differences between the farms sampled. Thus, levels in soil (ppm) were much higher than levels in water (ppb). Methoxychlor is the most frequently detected pesticide in soil and water and measured in highest concentrations in both matrices. This is unexpected since methoxychlor is considered much less persistent than other OC pesticides and is not legally used in Mexico, although it has been detected before in the environment in Sinaloa (Galindo-Reyes et al. 1992). Overall, in both soils and water the pesticides measured in higher concentrations were similar: in soils they were methoxychlor $>$ endosulfan sulfate $>$ endrin aldehyde $>$ aldrin, and in water they were methoxychlor $>$ endosulfan II $>$ endosulfan sulfate $>$ endrin aldehyde. Annual average concentrations were consistently higher in soils compared with water. Since almost all target OC pesticides were not in use in the area at the time of the study (endosulfans were not restricted although it is unclear whether they were still being used) it is expected that they should be mostly bound to soils due to past applications, which explains their higher concentrations in soils. The February sampling campaign coincided with the dry season in the study area while the August campaign coincided with the rainy season. Concentrations of most pesticides were higher during the rainy season in both soils and water. During the rainy season there is leaching into drainage canals which explains the higher concentrations in water compared to the dry season. In both soil and water $p, p-D D E$ concentrations were higher than $p, p$ '-DDT concentrations. Once applied, p,p'-DDT is known 
TABLE I. CONCENTRATIONS OF PESTICIDES IN SOIL AND WATER

\begin{tabular}{lcccc}
\hline Pesticide & $\begin{array}{c}\text { Soil } \\
(\mu \mathrm{g} / \mathrm{g})\end{array}$ & $\begin{array}{c}\text { Frequency of } \\
\text { detection }(\%)\end{array}$ & $\begin{array}{c}\text { Water } \\
(\mu \mathrm{g} / \mathrm{L})\end{array}$ & $\begin{array}{c}\text { Frequency of } \\
\text { detection }(\%)\end{array}$ \\
\hline$\alpha-\mathrm{HCH}$ & $1.097 \pm 1.059$ & 100 & $0.029 \pm 0.024$ & 93 \\
$\beta$-HCH & $1.070 \pm 0.567$ & 85 & $0.011 \pm 0.007$ & 8 \\
$\gamma$-HCH & $0.812 \pm 0.616$ & 100 & $0.038 \pm 0.023$ & 43 \\
$\delta$-HCH & $0.590 \pm 0.294$ & 43 & $0.048 \pm 0.039$ & 85 \\
Heptachlor & $1.128 \pm 0.553$ & 100 & $0.040 \pm 0.020$ & 85 \\
Heptachlor epoxide & $0.830 \pm 0.468$ & 79 & $0.081 \pm 0.070$ & 21 \\
Aldrin & $2.458 \pm 2.248$ & 38 & $0.052 \pm 0.046$ & 58 \\
Dieldrin & $1.340 \pm 0.791$ & 58 & $0.037 \pm 0.029$ & 58 \\
Endrin & $0.460 \pm 0.496$ & 50 & $0.033 \pm 0.028$ & 43 \\
Endrin aldehyde & $2.885 \pm 4.466$ & 71 & $0.133 \pm 0.078$ & 79 \\
Endosulfan I & $0.925 \pm 0.468$ & 85 & $0.090 \pm 0.148$ & 93 \\
Endosulfan II & $1.147 \pm 0.726$ & 43 & $0.331 \pm 0.205$ & 85 \\
Endosulfan sulfate & $6.903 \pm 5.183$ & 85 & $0.149 \pm 0.079$ & 100 \\
p,p'-DDE & $2.191 \pm 2.275$ & 100 & $0.054 \pm 0.062$ & 79 \\
p,p'-DDD & $1.448 \pm 0.864$ & 85 & $0.053 \pm 0.034$ & 100 \\
p,p'-DDT & $0.573 \pm 0.541$ & 58 & $0.023 \pm 0.007$ & 15 \\
Methoxychlor & $7.574 \pm 7.387$ & 100 & $0.565 \pm 0.445$ & 100 \\
SDDT & $3.759 \pm 3.362$ & & $0.099 \pm 0.069$ & \\
SHCHs & $3.079 \pm 2.322$ & & $0.085 \pm 0.068$ & \\
Famfur & $7.256 \pm 2.475$ & 94 & $1.530 \pm 1.199$ & 94 \\
Triethylphosphorothioate & $0.610 \pm 0.025$ & 19 & $0.089 \pm 0.032$ & 25 \\
Methyl parathion & $3.282 \pm 1.038$ & 44 & $0.750 \pm 0.264$ & 44 \\
Parathion & $2.223 \pm 0.726$ & 21 & $1.092 \pm 0.590$ & 31 \\
\hline
\end{tabular}

$\mathrm{HCH}$ : hexachlorocyclohexane; a-HCH, b-HCH, g-HCH, d-HCH: isomers of HCH; p',p'-DDE: ethylene metabolite of DD; p,p'-DDD: 1,1-dichloro-2,2-bis(p-chlorophenyl)ethane (another metabolite of dichlorodiphenyltrichloroethane, DDT)

to degrade to p,p'-DDE, so the p,p'-DDT/p,p'-DDE ratio is used as a rough indicator of the age of DDTs measured in the environment. The ratio of average $\mathrm{p}, \mathrm{p}$ '-DDT/p,p'-DDE is 0.26 in soils and 0.43 in water, indicating that DDTs measured in this study are aged.

Of the target organophosphate pesticides, only four were detected, as shown in table I. The order of frequency of detection was identical in both soils and water (famfur $>$ methyl parathion $>$ parathion $>$ triethylphosphorothioate), and the order of annual average concentrations were very similar. Frequency of detection ranged from $19 \%$ (parathion and triethylphosphorothioate) to $94 \%$ (famfur) in soils and from $25 \%$ (triethylphosphorothioate) to $94 \%$ (famfur) in water. These are current use pesticides in the area so similarities are expected. Concentrations in soils ranged from $0.610 \mu \mathrm{g} / \mathrm{g}$ (triethylphosphorothioate) to $7.256 \mu \mathrm{g} / \mathrm{g}$ (famfur), and in waters from $0.089 \mu \mathrm{g} / \mathrm{L}$ (triethylphosphorothioate) to $1.530 \mu \mathrm{g} / \mathrm{L}$ (famfur). As with OC pesticides, concentrations were higher in soils compared with water, as evidenced by the fact that concentrations in the former were in the ppm range, while in the latter they were in the ppb range. These pesticides degrade more readily with much lower half-lives compared with OC pesticides. Therefore, they are more likely to be degraded before there is time to be transported to drainage canals. Nonetheless, they are more soluble than OC pesticides and more susceptible to rain washout into drainage canals. As a result, concentrations in water are higher than those of OC pesticides and the difference in concentrations between soils and water is not as marked as with OC pesticides.

\section{Pesticide concentrations in blood and urine}

The concentrations of pesticides in blood and urine of volunteers are summarized in table II.

In farmworkers, 14 of 17 target OC pesticides were detected in blood in at least one sample, while in urine seven of 10 target OP pesticides were detected in at least one sample. The frequency of detection of those pesticides detected ranged from $9 \%$ (dieldrin) to $91 \%$ (heptachlor epoxide and p,p'-DDE) in blood and from $9 \%$ (diazinon) to $91 \%$ (famfur) in urine. In comparison, in the control group only six OC pesticides were detected in blood and in urine only three OP pesticides were detected in at least one sample. The frequency of detection of those pesti- 
TABLE II. CONCENTRATIONS OF PESTICIDES IN BLOOD AND URINE

\begin{tabular}{|c|c|c|c|c|}
\hline \multirow[t]{2}{*}{ Pesticide } & \multicolumn{2}{|c|}{ FARMWORKERS } & \multicolumn{2}{|c|}{ CONTROL } \\
\hline & $\begin{array}{c}\text { Blood } \\
(\mu \mathrm{g} / \mathrm{mL})\end{array}$ & $\begin{array}{l}\text { Frequency of } \\
\text { detection }(\%)\end{array}$ & $\begin{array}{c}\text { Blood } \\
(\mu \mathrm{g} / \mathrm{mL})\end{array}$ & $\begin{array}{l}\text { Frequency of } \\
\text { detection }(\%)\end{array}$ \\
\hline$\alpha-\mathrm{HCH}$ & $2.68 \pm 0.32$ & 36 & $\mathrm{Bd}$ & 0 \\
\hline$\beta-\mathrm{HCH}$ & $5.34 \pm 2.15$ & 82 & $\mathrm{Bd}$ & 0 \\
\hline$\gamma-\mathrm{HCH}$ & $1.32 \pm 0.16$ & 9 & $0.25^{\mathrm{b}}$ & 5 \\
\hline$\delta-\mathrm{HCH}$ & $2.34 \pm 0.85$ & 73 & $\mathrm{Bd}$ & 0 \\
\hline Heptachlor & $7.69 \pm 3.41$ & 73 & $\mathrm{Bd}$ & 0 \\
\hline Heptachlor epoxide & $5.71 \pm 3.12$ & 91 & $\mathrm{Bd}$ & 0 \\
\hline Aldrin & $1.76 \pm 0.87$ & 64 & $\mathrm{Bd}$ & 0 \\
\hline Dieldrin & $3.36 \pm 0.91$ & 9 & $\mathrm{Bd}$ & 0 \\
\hline Endrin & $\mathrm{Bd}$ & 0 & $\mathrm{Bd}$ & 0 \\
\hline Endrin aldehyde & $\mathrm{Bd}$ & 0 & $\mathrm{Bd}$ & 0 \\
\hline Endosulfan I & $7.04 \pm 7.85$ & 36 & $0.65^{\mathrm{b}}$ & 10 \\
\hline Endosulfan II & $4.03 \pm 1.32$ & 18 & $0.45^{\mathrm{b}}$ & 5 \\
\hline Endosulfan sulfate & $4.35 \pm 0.68$ & 18 & $0.55^{\mathrm{b}}$ & 10 \\
\hline $\mathrm{p}, \mathrm{p}^{\prime}-\mathrm{DDE}$ & $13.61 \pm 12.71$ & 91 & $1.12 \pm 1.05$ & 20 \\
\hline p,p'-DDD & $\mathrm{Bd}$ & 91 & $\mathrm{Bd}$ & 0 \\
\hline p,p'-DDT & $2.73 \pm 0.74$ & 18 & $0.35^{\mathrm{b}}$ & 10 \\
\hline \multirow[t]{2}{*}{ Methoxychlor } & $240 \pm 265$ & 73 & $\mathrm{Bd}$ & 0 \\
\hline & $\begin{array}{c}\text { Urine } \\
(\mu \mathrm{g} / \mathrm{mL})\end{array}$ & $\begin{array}{l}\text { Frequency of } \\
\text { detection }(\%)\end{array}$ & $\begin{array}{c}\text { Urine } \\
(\mu \mathrm{g} / \mathrm{mL})\end{array}$ & $\begin{array}{l}\text { Frequency of } \\
\text { detection }(\%)\end{array}$ \\
\hline Famfur & $20.87 \pm 13.70$ & 91 & $\mathrm{Bd}$ & 0 \\
\hline Triethylphosphorothioate & $\mathrm{Bd}$ & 0 & $\mathrm{Bd}$ & 0 \\
\hline Methyl parathion & $4.34 \pm 2.80$ & 91 & $0.95 \pm 0.55$ & 20 \\
\hline Parathion & $2.38 \pm 2.00$ & 36 & $0.36 \pm 0.30$ & 25 \\
\hline Disulfuton & $3.49 \pm 3.80$ & 18 & $\mathrm{Bd}$ & 0 \\
\hline Dimethoate & $5.79 \pm 2.70$ & 36 & $\mathrm{Bd}$ & 0 \\
\hline Thionazin & $0.33 \pm 0.15$ & 18 & $\mathrm{Bd}$ & 0 \\
\hline Diazinon & $9.61 \pm 2.98$ & 9 & $1.65^{\mathrm{b}}$ & 10 \\
\hline Phorate & $\mathrm{Bd}$ & 0 & $\mathrm{Bd}$ & 0 \\
\hline Sulfotep & $\mathrm{Bd}$ & 0 & $\mathrm{Bd}$ & 0 \\
\hline
\end{tabular}

binsufficient samples to calculate the standard deviation

Bd: below detection; $\mathrm{HCH}$ : hexachlorocyclohexane: a-HCH, b- $\mathrm{HCH}$, g- $\mathrm{HCH}, \mathrm{d}-\mathrm{HCH}$ : isomers of $\mathrm{HCH}$; p',p'-DDE: ethylene metabolite of DD; p,p'-DDD: 1,1-dichloro-2,2-bis(p-chlorophenyl)ethane (another metabolite of dichlorodiphenyltrichloroethane, DDT)

cides detected ranged from $5 \%$ (g-HCH and endosulfan II) to $20 \%$ (p,p'-DDE) in blood and from $10 \%$ (diazinon) to $25 \%$ (parathion) in urine. Levels of pesticides were consistently higher in blood and urine from farmworkers compared to the control group, statistically significantly $(p<0.05)$ in the few cases where the number of samples in the latter allowed for statistical comparisons. The p,p'-DDT/p,p'-DDE ratio in urine of farmworkers is 0.20 , similar to the ratios in soil and water.

\section{Clinical data}

Results of the clinical analyses carried out in blood are shown in table III. The results show that levels of glutamic pyruvic transaminase, glutamic
TABLE III. RESULTS OF CLINICAL ANALYSES

\begin{tabular}{lcc}
\hline Parameter & $\begin{array}{c}\text { Farmworkers } \\
(\mathrm{n}=49)\end{array}$ & $\begin{array}{c}\text { Control } \\
(\mathrm{n}=20)\end{array}$ \\
\hline $\begin{array}{l}\text { Glutamic pyruvic } \\
\text { transaminase (IU/L) }\end{array}$ & $74.9 \pm 20.0$ & $31.0 \pm 11.0$ \\
$\begin{array}{l}\text { Glutamic oxaloacetic } \\
\text { transaminase (IU/L) }\end{array}$ & $59.3 \pm 13.5$ & $32.0 \pm 8.12$ \\
$\begin{array}{l}\text { Alkaline phosphatase } \\
(\mathrm{IU} / \mathrm{L})\end{array}$ & $192.8 \pm 71.3$ & $123 \pm 32.2$ \\
$\begin{array}{l}\text { Hemoglobin (g/dL) } \\
\text { Acetylcholinesterase } \\
(\mathrm{U} / \mathrm{L})\end{array}$ & $12.6 \pm 0.98$ & $14.9 \pm 0.82$ \\
\hline
\end{tabular}

IU: international units, U: units 
oxalacetic transaminase, and alkaline phosphatase were significantly elevated in farmworkers compared to the control group $(p<0.05)$, while levels of hemoglobin and acetylcholinesterase were significantly depressed $(\mathrm{p}<0.05)$.

\section{DISCUSSION}

The similarity in pesticide profiles between soil/ water and blood/urine strongly suggests that their presence in the latter is a direct result of chronic exposure of farmworkers to these chemicals. The fact that most OC target pesticides (with the exception of endosulfans) were not being used at the time of the study yet they were found in blood and urine supports the chronic exposure hypothesis. This is supported further by the similarity in ratios of p,p'-DDT/p,p'DDE calculated in all matrices, indicating the presence of aged DDTs in both environmental and tissue samples. The presence of OC pesticides in blood indicates their accumulation in diverse organs and/or tissues, which represents an increased probability of cancer in the prostate, liver, thyroid, blood, etc. While OP pesticides degrade more quickly compared with OC pesticides, their presence in urine of farmworkers also suggests that they are suffering from workplace exposure to chemicals employed in agriculture in the area. The lower frequency of detection of both classes of pesticides and statistically significantly lower levels $(p<0.05)$ of those that were detected in the control population compared to the farmworkers supports the hypothesis that exposure of farmworkers occurred via workplace exposure.

Table IV (compiled from data in Hansen et al. 2013), shows the maximum levels of some pesticides permitted in drinking water in different countries and in soil before remediation as required in the Netherlands. With respect to water, a comparison of the average levels measured in this study with those of Hansen et al. (2013) indicate that levels of heptachlor and heptachlor epoxide were higher than allowed in the European Union and Mexico. Also, levels of aldrin were higher than those allowed in the European Union, Mexico and Canada, and levels of dieldrin were higher than those allowed in the $\mathrm{Eu}-$ ropean Union and Mexico, and by the World Health Organization. In addition, the upper range values of heptachlor were higher than the maximum allowed in the USA. In the case of dieldrin, they were higher than in Canada, and for endosulfans and p,p'-DDE higher than in the European Union. With respect to soil, average levels of heptachlor epoxide and individual values in the upper range for $\mathrm{g}-\mathrm{HCH}$, dieldrin, aldrin, and endrin were higher than the maximum values allowed in the Netherlands. These results suggest there is reason for concern about chronic exposure of farmworkers to the agricultural pesticides comprised in this study.

It has been demonstrated that pesticides inhibit or alter normal levels of the chemical parameters measured in this study. The results indicate that,

TABLE IV. MAXIMUM ALLOWED CONCENTRATIONS OF SELECTED PESTICIDES IN WATER AND SOILS.

\begin{tabular}{llc}
\hline Pesticide & Water (mg/L) & Soil (mg/g) \\
\hline$\alpha-\mathrm{HCH}$ & & 3 \\
$\beta$-HCH & & 9 \\
$\gamma$-HCH & $0.1(\mathrm{EU}), 0.2(\mathrm{USA}), 2(\mathrm{WHO}, \mathrm{MX})$ & 0.05 \\
Heptachlor & $0.03(\mathrm{EU}, \mathrm{MX}), 0.4(\mathrm{USA})$ & 0.7 \\
Heptachlor epoxide & $0.03(\mathrm{EU}, \mathrm{MX}), 0.2(\mathrm{USA})$ & 0.0007 \\
Aldrin & $0.03(\mathrm{EU}, \mathrm{MX}, \mathrm{CAN}), 0.7(\mathrm{WHO})$ & 0.06 \\
Dieldrin & $0.03(\mathrm{EU}, \mathrm{MX}, \mathrm{WHO}), 0.7(\mathrm{CAN})$ & 0.5 \\
Endrin & $0.1(\mathrm{EU}), 0.6(\mathrm{WHO}), 2$ (USA) & 0.04 \\
Endosulfan & $0.1(\mathrm{EU})$ & 10 \\
DDT and metabolites & $0.1(\mathrm{EU}), 1(\mathrm{WHO}, \mathrm{MX})$ & \\
Methoxychlor & $20(\mathrm{WHO}, \mathrm{MX}), 40(\mathrm{USA}), 900(\mathrm{CAN})$ & \\
Parathion & $50(\mathrm{CAN})$ & \\
Diazinon & $20(\mathrm{CAN})$ & \\
\hline
\end{tabular}

Table compiled from data in Hansen et al., 2013

EU: European Union; USA: United States of America; WHO: World Health Organization; MX: Mexico; CAN: Canada; $\mathrm{HCH}$ : hexachlorocyclohexane; a-HCH, b-HCH, $\mathrm{g}-\mathrm{HCH}$ : isomers of $\mathrm{HCH}$; DDT: dichlorodiphenyltrichloroethane 
compared to the control group, levels of transaminases, as well as the alkaline phosphatase were statistically elevated while levels of hemoglobin and acetylcholinesterase were statistically reduced $(\mathrm{p}<$ 0.05 ) in farmworkers. These results are indicators of frequent exposure to pesticides, particularly OP pesticides. It has been reported that due to their high reactivity, organophosphate pesticides alter not only the levels of acetylcholinesterase but also the function of a number of enzymes and proteins.

Inhibition of acetylcholinesterase, a neurotransmitter in humans and many other organisms, affects nervous functions, especially the contractionrelaxation of the diaphragm, which in turn provokes fatigue and breathing difficulties. Low levels of this enzyme can also indicate congenital deficiency, hepatic damage and risk of infarction (Čolović et al. 2013, Perwitasari et al. 2017). Similarly, elevated levels of transaminase enzymes can be correlated with improper liver function, which can in turn lead to cancer or alterations in the functions of this vital organ. Elevated levels of transaminases are also indicative of necrosis of the liver and myocardium, and in general of hepatocellular damage resulting from exposure to toxic substances (Limdi and Hyde 2003). Glutamine pyruvic transaminase is an enzyme found in the liver in high concentrations and in the kidneys, heart and muscles in lower levels, while glutamic oxalacetic transaminase is concentrated in the heart, liver and muscles. When these organs are damaged, these enzymes are released into the blood stream, which results in elevated levels in blood samples. Elevated levels of the enzyme alkaline phosphatase have been associated with hepatic diseases, bone cancer, leukemia and thyroid damage (D'Ocon et al. 2006). Depressed levels of hemoglobin in farmworkers compared with the control group suggest the former are suffering from anemia and undernourishment. It is especially noteworthy that DDT metabolite p,p'-DDE was found in significant levels in urine in farmworkers, as this chemical has been classified as a possible human carcinogen by the United States Environmental Protection Agency (USEPA 2016). Previous studies have reported that OC pesticides tend to accumulate in different tissues and are cancer inducers, endocrine disruptors (Kester 2001) and exert other toxicological effects (Bejarano 2002, Moreno 2003, Beard 2006, Klaasseen 2013).

Chronic exposure is of great concern due to their adverse health effects. Exposure to organophosphate pesticides has been implicated in prolonged impairment of cognitive functions, including memory and attention, as well as chronic illnesses (Terry 2012). Studies have shown that organophosphate pesticides are potential endocrine disruptors with the capacity to disrupt the male sexual hormone profile in men who are occupationally and environmentally exposed to them (Padungtod et al. 1998, Kang et al. 2004, Meeker et al. 2006, Recio-Vega et al. 2008, Blanco-Muñoz et al. 2012). A recent review on the health effects of organophosphate pesticides reported that many studies have demonstrated a correlation between chronic exposure to these chemicals among adults and neurologic effects, DNA damage and adverse birth outcomes (Koureas et al 2012). Bolognesi (2003) reported that in occupationally exposed populations, including farmworkers, there was a positive association between exposure to complex pesticide mixtures and the presence of chromosomal aberrations, sister-chromatid exchanges and micronuclei, although a number of the studies did not detect cytogenetic damage. In general, genetic damage associated with pesticides occurs in populations exposed to high levels due to intensive usage. Bortoli et al. (2009) reported that a study comparing 29 Brazilian workers exposed to pesticides in soybean fields with 37 control individuals showed that the mean number of cells with micronuclei in the former was significantly higher in the former $(3.55 \pm 2.13)$ compared with the latter $(1.78 \pm 1.23)$. Exposure to pesticides, especially organophosphate pesticides, has been associated with increased incidence of non-Hodgkin's lymphoma, multiple myeloma, soft tissue sarcoma, lung sarcoma, and cancer of the pancreas, stomach, liver, bladder and ball bladder, Parkinson disease, Alzheimer disease, and reproductive outcomes (Kapka-Skrzypczak et al. 2011).

\section{CONCLUSIONS}

The fact that the types of pesticides measured in blood and urine of farmworkers are the same as those measured in water and soils of the study area, indicates that farmworkers suffer from chronic exposure to these chemicals in their workplace. This is supported by the fact that the types and levels of pesticides measured in a control group not involved in farming are much lower. The elevated levels of transaminases and the alkaline phosphatase, as well as depressed levels of hemoglobin and acetylcholinesterase in farmworkers compared with the control population indicate that the chronic exposure of farmworkers is adversely affecting their health. Although not a part of this study, a survey carried out 
among farmworkers regarding the types of medical ailments they were treated for in local clinics reported frequent headaches and fatigue, nervous alterations, breathing difficulties, and liver and stomach problems (Galindo-Reyes, unpublished), all of which supports this conclusion.

\section{REFERENCES}

Alavanja M.C.R. and Bonner M. (2012). Occupational pesticide exposures and cancer risk: A review. J. Toxicol. Env. Heal. B 15 (4), 238-263.

DOI: $10.1080 / 10937404.2012 .632358$

Andreoli C.V. (1993). La influencia de la agricultura sobre la calidad del agua. In: Prevención de la contaminación del agua por la agricultura y actividades relacionadas. Actas de la Consulta de Expertos de la FAO, Santiago, Chile, 20-23 de octubre. Organización de las Naciones Unidas para la Agricultura y la Alimentación, España, 59-73.

Beard J. (2006). DDT and human health. Sci. Tot. Environ. 355, 78-89. DOI: 10.1016/j.scitotenv.2005.02.022

Bejarano G.F. (2002). La espiral del veneno. Guía crítica ciudadana sobre plaguicidas. RAPAM, Texcoco, Mexico, 226 pp.

Blanc-Lapierre A., Bouyier G., Gruber A., Leffondre K., Lebailly P., Fabrigoule C. and Baldi I. (2013). Cognitive disorders and occupational exposure to organophosphates: Results from the PHYTONER study. Am. J. Epidemiol. 177, 1086-1096.

DOI: 10.1093/aje/kws346

Blanco-Muñoz J., Lacasana M., Aguilar-Garduno C., Rodríguez-Barranco M., Bassol S., Cebrián M.E., López-Flores I. and Ruiz-Pérez I. (2012). Effect of exposure to $\mathrm{p}, \mathrm{p}-\mathrm{DDE}$ on male hormone profile in Mexican flower growers. Occup. Environ. Med. 69, 5-11. DOI: 10.1136/oem.2010.059667

Bolognesi C. (2003). Genotoxicity of pesticides: A review of human biomonitoring studies. Mutat. Res. 543 (3), 251-272.

DOI: $10.1016 / \mathrm{S} 1383-5742(03) 00015-2$

Bortoli G.M., Azevedo M.B. and Silva L.B. (2009). Cytogenetic biomonitoring of Brazilian workers exposed to pesticides: Micronucleus analysis in buccal epithelial cells of soybean growers. Mutat. Res. 675 (1-2), 1-4. DOI: 10.1016/j.mrgentox.2009.01.001

Bro-Rasmussen F. (1996). Contamination by persistent chemicals in food chain and human health. Sci. Tot. Environ. 188, S45-S60. DOI: $10.1016 / 0048-9697(96) 05276-X$

CNR (1983). Metodologie analitiche per lo studio della qualita dell'ambiente marino. Consiglio Nazionale delle Richerche, Geneva, Italy, 192 pp.
COFEPRIS (2015). Catálogo de plaguicidas. De la A a la Z plaguicidas y fertilizantes. Comisión Federal para la Protección contra Riesgos Sanitarios [online]. http:// www.cofepris.gob.mx/AZ/Paginas/Plaguicidas $\% 20$ y\%20Fertilizantes/CatalogoPlaguicidas.aspx

Čolović M.B., Krstić D.Z., Lazarević-Pašti T.D., Bondžić A.M. and Vasić V.M. (2013). Acetylcholinesterase inhibitors: Pharmacology and toxicology. Curr. Neuropharmacol. 11 (3), 315-335.

DOI: $10.2174 / 1570159 X 11311030006$

De-Qing W., Yu Y.-X., Zhang X.-Y., Zhang S.-H., Pang Y.-P., Zhang X.-L., Yu Z.-Q., Wu M.-H. and Fu J.-M. (2012). Polycyclic aromatic hydrocarbons and organochlorine pesticides in fish from Taihu Lake: Their levels, sources, and biomagnification. Ecotoxicol. Environ. Safety 82, 63-70.

DOI: 10.1016/j.ecoenv.2012.05.010

Dhouib I.B., Annabi A., Jallouli M., Marzouki S., Gharbi N., Elfazaa S. and Montassar Lasram M. (2016). Carbamates pesticides induced immunotoxicity and carcinogenicity in human: A review. J. Appl. Biomed. 14, 85-90. DOI: 10.1016/j.jab.2016.01.001

D’Ocon N.C., García-García S.M. and Vicente G.J. (2006). Fundamentos y técnicas de análisis bioquímicos. Thomson-Paraninfo, Madrid, Spain, 280 pp.

FAO (1993). Las políticas de recursos hidricos y la agricultura. In: El estado mundial de la agricultura y la alimentación 1993. Food and Agriculture Organization, Rome, Italy, 230-293 (FAO: Agricultura 26).

Freeman L.E.B., Bonner M.R., Blair A., Hoppin J.A., Sandler D.P., Lubin J.H., Dosemeci M., Lynch C.F., Knott C. and Alavanja M.C.R. (2005). Cancer incidence among male pesticide applicators in the Agicultural Health Study cohort exposed to diazinon. Am. J. Epidemiol. 162, 1070-1079. DOI: 10.1093/aje/wi321

Galindo Reyes J.G., Guerrero Ibarra M., Villagrana Lizárraga C., Quezada Urenda L. and Angulo Escalante S. (1992). Contaminacion por plaguicidas en agua, sedimentos, camarón y almejas de dos ecosistemas costeros de Sinaloa, México. Tropical Ecology 33 (2), 172-180.

Galindo Reyes J.G., Medina Jasso M.A., Villagrana Lizárraga C. and Ibarra C.L. (1997). Environmental and pollution condition of the Huizache-Caimanero Lagoon in the north-west of Mexico. Mar. Pollut. Bull. 34, 1072-1077. DOI: 10.1016/S0025-326X(97)00081-7

Hansen A.M., Trevino-Quintanilla L.G., Márquez-Pacheco H., Villada-Canela M., Gonzalo-Márquez L.C., Guillén-Garcés R.A. and Hernández-Antonio A. (2013). Atrazina: un herbicida polémico. Rev. Int. Contam. Ambie. 29, 65-84.

IARC (2017). Some organophosphate insecticides and herbicides. In: Monographs on the evaluation of carcinogenic risks to humans, vol. 112. International 
Agency for Research on Cancer, Lyon, France, 454 pp. [online] http://monographs.iarc.fr/ENG/Monographs/ vol112/mono112.pdf 06/07/2017.

INEGI (2016). Anuario estadístico y geográfico de Sinaloa. Instituto Nacional de Estadística y Geografía, Mexico [online]. http://internet.contenidos.inegi. org.mx/contenidos/Productos/prod_serv/contenidos/ espanol/bvinegi/productos/nueva_estruc/anuarios_2016/702825083687.pdf 10/07/2017.

Kang H., Jeong S., Cho J., Kim D., Park J. and Cho M. (2004). Chlropyrifos-methyl shows anti-androgenic activity without estrogenic activity in rats. Toxicology 199, 219-230. DOI: 10.1016/j.tox.2004.02.025

Kapka-Skrzypczak L., Cyranka M., Skrzypczak M. and Kruszewski M. (2011). Biomonitoring and biomarkers of organophosphate pesticides exposure - state of the art. Ann. Agric. Environ. Med. 18 (2), 294-303.

Kester J.E. (2001). Endocrine-disrupting chemicals. In: Clinical environmental health and toxic exposures (J.B. Sullivan, G.R. Krieger, Eds.) Lippincott William and Wilkins, Philadelphia, USA, 362-373.

Klaassen C. (2013). Casarett and Doull's toxicology. The basic science of poisons. McGraw- Hill (Medical), New York, USA, 1454 pp.

Koureas M., Tsakalof A., Tsatsakis A. and Hadjichristodoulou C. (2012). Systematic review of biomonitoring studies to determine the association between exposure to organophosphorus and pyrethroid insecticides and human health outcomes. Toxicol. Lett. 210 (2), 155168. DOI: $10.1016 / j$.toxlet.2011.10.007

Lacasaña M., López-Flores I., Rodríguez-Barranco M., Aguilar-Garduño C., Blanco-Muñoz J., Pérez-Méndez O., Gamboa R., González-Alzaga B., Bassol S. and Cebrián M.E. (2010). Interaction between organophosphate pesticide exposure and PON1 activity on thyroid function. Toxicol. Appl. Pharmacol. 249, 16-24. DOI: 10.1016/j.taap.2010.07.024

Lee W.J., Blair A., Hoppin J.A., Lubin J.H., Rusiecki J.A., Sandler D.P., Dosemeci M. and Alavanja M.C.R. (2004). Cancer incidence among pesticide applicators exposed to chlorpyrifos in the Agricultural Health Study. J. Natl. Cancer Inst. 96, 1781-1789.

DOI: 10.1093/jnci/djh324

Limdi J.K. and Hyde G.M. (2003). Evaluation of abnormal liver function tests. Med. J. 79, 307-312.

DOI: $10.1136 / \mathrm{pmj} .79 .932 .307$

Luo D., Pu Y., Tian H., Cheng J., Zhou T., Tao Y., Yuan J., Sun X. and Mei S. (2016). Concentrations of organochlorine pesticides in umbilical cord blood and related lifestyle and dietary intake factors among pregnant women of the Huaihe River Basin in China. Environ. Int. 92-93, 276-283.

DOI: $10.1016 /$ j.envint.2016.04.017
Meeker J., Ryan L., Barr D. and Hauser R. (2006). Exposure to nonpersistent insecticides and male reproductive hormones. Epidemiology 17, 61-68.

DOI: 10.1097/01.ede.0000190602.14691.70

Michalakis M., Tzatzarakis M.N., Kovatsi L., Alegakis A.K., Tsakalof A.K., Heretis I. and Tsatsakis A. (2014). Hypospadias in offspring is associated with chronic exposure of parents to organophosphate and organochlorine pesticides. Toxicol. Lett. 230 (2), 139-145. DOI: $10.1016 /$ j.toxlet.2013.10.015

Moreno G.M. (2003). Toxicología ambiental. Evaluación de riesgo para la salud humana. McGraw Hill/Interamericana de España, Madrid, Spain, 384 pp.

Nilsen E., Zaugg S., Alvarez D., Morace J., Waite I., Counihan T., Hardiman J., Torres L., Patiño R., Mesa M. and Grove R. (2014). Contaminants of legacy and emerging concern in large scale suckers (Catostomus macrocheilus) and the foodweb in the lower Columbia River, Oregon and Washington, USA. Sci. Tot. Environ. 484, 344-352. DOI: 10.1016/j.scitotenv.2013.04.012

Padungtod C., Lasley B., Christiani D., Ryan L. and Xu X. (1998). Reproductive hormone profile among pesticide factory workers. J. Occup. Environ. Med. 40, 1038-1047.

Perwitasari D.A., Prasasti D., Supadmi W., Dewi Jaikishin S.A. and Wiraagni I.A. (2017). Impact of organophosphate exposure on farmers' health in Kulon Progo, Yogyakarta: Perspectives of physical, emotional and social health. SAGE Open Med. 5, 1-6.

DOI: $10.1177 / 2050312117719092$

Piccoli C., Cremonese C., Koifman R.J., Koifman R. and Freire C. (2016). Pesticide exposure and thyroid function in an agricultural population in Brazil. Environ. Res. 151, 389-398. DOI: 10.1016/j.envres.2016.08.011

Polanco Rodríguez A.G., Riba López M.I., Del Valls Casillas T.A., Araujo León J.A., Mahjoub O. and Prusty A.K. (2017). Monitoring of organochlorine pesticides in blood of women with uterine cervix cancer. Environ. Pollut. 220 Part B, 853-862.

DOI: $10.1016 /$ j.envpol.2016.10.068

Ramírez-López J.A. and Galindo-Reyes J.G. (2014). Los agroquímicos en la region sur del Estado de Sinaloa. Servicios Editoriales Once Ríos, Culiacán, Sinaloa, Mexico, 173 pp.

Recio-Vega R., Ocampo-Gómez G., Morán-Martínez J., Borja-Aburto V., López-Cervantes M., Uribe M., Torres-Sanchez L. and Cebrián M.E. (2005). Pesticide exposure alters follicle-stimulating hormone levels in Mexican agricultural workers. Environ. Health Perspect. 113 (9), 1160-1163.

Recio-Vega R., Ocampo-Gómez G., Borja-Aburto V.H., Morán-Martínez J. and Cebrián Garcia M.E. (2008). Organophosphorus pesticide exposure decreases sperm 
quality: association between sperm parameters and urinary pesticide levels. J. Appl. Toxicol. 28, 674-680. DOI: $10.1002 /$ jat. 1321

Rickert D. (1993). Water quality assessment to determine the nature and extent of water pollution by agriculture and related activities. Prevention of water pollution by agriculture and related activities. Proceedings of the FAO Expert Consultation, Santiago, Chile, October 20-23. Food and Agriculture Organization, Rome, Italy, pp. 171-194.

SAGARPA (2011). Estimacion de las exportaciones agroalimentarias a nivel de entidad federativa. Secretaría de Agricultura, Ganadería, Pesca y Acuacultura. [online] http://www.sagarpa.gob.mx/agronegocios/ Documentos/pablo/Documentos/Estima_Exp_Edo. pdf 23/07/2017

Starks S.E., Hoppin J.A., Kamel F., Lynch C.F., Jones M.P., Alavanja M.C., Sandler D.P. and Gerr F. (2012). Peripheral nervous system function and organophosphate pesticide use among licensed pesticide applicators in the agricultural health study. Environ. Health Perspect. 120, 515-520. DOI: 10.1289/ehp.1103944

Terry A.V. (2012). Functional consequences of repeated organophosphate exposure: potential non-cholinergenic mechanisms. Pharmacol. Ther. 134, 355-365.

DOI: $10.1016 /$ j.pharmthera.2012.03.001

Thomas A., Leontjew Toms L.M., Harden F.A., Hobson P., White N.M., Mengersen K.L. and Muller J.F. (2017). Concentrations of organochlorine pesticides in pooled human serum by age and gender. Environ. Res. 154, 10-18 DOI: 10.1016/j.envres.2016.12.009

USEPA (2016). Integrated risk information system (IRIS) on p,pDichlorodiphenyldichloroethylene. National Center for Environmental Assessment, Office of Research and Development, Environmental Protection Agency, Washington, USA. [online] http://www.epa. gov/sites/production/files/2016-09/documents/dde. pdf 03/09/2017 